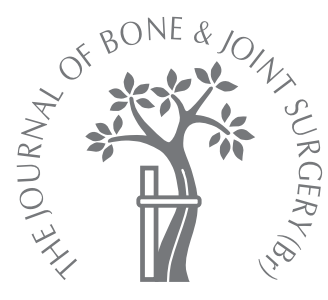

\title{
The treatment of deep shoulder infection and glenohumeral instability with debridement, reverse shoulder arthroplasty and post- operative antibiotics
}

D. J. Cuff,

N. A. Virani, J. Levy, M. A. Frankle,

A. Derasari,

B. Hines,

D. R. Pupello,

M. Cancio,

M. Mighell

From the Florida

Orthopaedic Institute

Research Foundation,

Tampa, Florida

D. J. Cuff, MD, Consultant

Orthopaedic Surgeon

N. A. Virani, MD, Orthopaedic

Resident

M. A. Frankle, MD,

Consultant Orthopaedic

Surgeon

II. R. Pupello, BS

Research Staff

M. Mighell, MD, Consultant

Orthopaedic Surgeon,

Florida Orthopaedic Institute

13020 N Telecom Parkway,

Tampa, Florida 33637, USA.

In J. Levy, MD, Consultant

Orthopaedic Surgeon

Orthopaedic Institute

Holy Cross Hospital, 4275 North

Federal Highway, $\mathrm{Ft}$

Lauderdale, FL 33308, USA

A. Derasari, BS, Medical

Student

University of South Florida

College of Medicine, 12901

Bruce B. Dawns Blvd, MDC 2,

Tampa, Florida 33612, USA.

B. Hines, DO, Consultant

Orthopaedic Surgeon

Memorial Hospital, York, $325 \mathrm{~S}$

Belmont St, PA 17405, USA.

M. Cancio, MD, Consultant

Physician

Infectious Disease Associate

of Tampa Bay, 4 Columbia

Drive \#820, Tampa, Florida

33606, USA.

Correspondence should be sent to Dr M. A. Frankle; e-mail: frankle@pol.net

(C)2008 British Editorial Society of Bone and Joint Surgery

doi:10.1302/0301-620X.90B3. $19408 \$ 2.00$

$J$ Bone Joint Surg $[B r]$ 2008;90-B:336-42.

Received 6 March 2007;

Accepted after revision 28

September 2007

We retrospectively reviewed 21 patients (22 shoulders) who presented with deep infection after surgery to the shoulder, 17 having previously undergone hemiarthroplasty and five open repair of the rotator cuff. Nine shoulders had undergone previous surgical attempts to eradicate their infection. The diagnosis of infection was based on a combination of clinical suspicion (16 shoulders), positive frozen sections ( $>5$ polymorphonuclear leukocytes per high-power field) at the time of revision (15 shoulders), positive intra-operative cultures (18 shoulders) or the pre-operative radiological appearances. The patients were treated by an extensive debridement, intravenous antibiotics, and conversion to a reverse shoulder prosthesis in either a single- (10 shoulders) or a two-stage (12 shoulders) procedure.

At a mean follow-up of 43 months (25 to 66) there was no evidence of recurrent infection. All outcome measures showed statistically significant improvements. Mean abduction improved from $36.1^{\circ}$ (SD 27.8) pre-operatively to $75.7^{\circ}$ (SD 36.0$)(p<0.0001$ ), the mean forward flexion from $43.1^{\circ}$ (SD 33.5) to $79.5^{\circ}$ (SD 43.2) ( $p=0.0003$ ), and mean external rotation from $10.2^{\circ}$ (SD 18.7) to $25.4^{\circ}$ (SD 23.5) ( $p=0.0037$ ). There was no statistically significant difference in any outcome between the single-stage and the two-stage group.

Historically, the treatment of deep infection after soft-tissue or joint replacement procedures of the shoulder has consisted of aggressive debridement and extensive courses of antibiotics. If the infection can be eliminated, further reconstruction can be undertaken. The ability to eradicate the infection is often related directly to the quality of the debridement. ${ }^{1-3}$ The shoulder presents a difficult problem in that the infection and subsequent aggressive debridement can compromise the rotator cuff and other stabilising structures, rendering the joint unstable.

The aims of treatment are to eliminate infection, reduce pain, and restore function. Previously, the options for reconstruction following deep sepsis in the shoulder have been limited. We considered that after debridement, reverse shoulder arthroplasty could be used to stabilise the joint allowing restoration of function, and that further antibiotics could be used to assist in eliminating the infection. We employed a standard intra-operative protocol to obtain tissue and fluid in order to devise an appropriate regimen of antibiotics after surgery. We have assessed the short-term results of single- or multiple-stage treatment using debridement, reverse shoulder arthroplasty and post-operative antibiotics to manage the triad of deep infection, rotator cuff deficiency and glenohumeral instability.

\section{Patients and Methods}

Between December 1998 and April 2005, 25 shoulders in 24 patients with severe rotator cuff deficiency and a painful shoulder secondary to infection were treated with debridement, implantation of a reverse shoulder arthroplasty and intravenous (IV) antibiotics. Of these patients, three died leaving 21 (ten men and 11 women) (22 shoulders) with a minimum of two years' follow-up. The mean age at the time of operation was 67 years (43 to 83). The mean follow-up was 43 months (25 to 66). The patient demographics are shown in Table I.

A hemiarthroplasty had previously been performed on 17 shoulders, but the remaining five had no prior joint replacement. In 13 $(77 \%)$ of the shoulders with a hemiarthroplasty, the procedure had been undertaken following a fracture, three $(18 \%)$ had been undertaken for rotator cuff arthropathy, and the reason for one $(5 \%)$ was unknown. The five shoulders without an arthroplasty had undergone an attempted open rotator cuff repair; one had also had an acromioplasty, and another internal fixation at the time of the cuff repair. A previous debridement had been undertaken on nine of the 22 shoulders $(40.9 \%)$ of which six had undergone more than one operation before referral. 
Table I. Patient demographics, and radiological analysis

\begin{tabular}{|c|c|c|c|c|c|c|c|c|}
\hline \multirow[b]{2}{*}{ Shoulders } & \multirow[b]{2}{*}{ Gender } & \multirow[b]{2}{*}{$\begin{array}{l}\text { Age at RSP* } \\
\text { (yrs) }\end{array}$} & \multirow[b]{2}{*}{$\begin{array}{l}\text { Prior hemi- } \\
\text { arthroplasty }\end{array}$} & \multirow[b]{2}{*}{$\begin{array}{l}\text { Number } \\
\text { of stages }\end{array}$} & \multirow[b]{2}{*}{$\begin{array}{l}\text { Follow-up } \\
\text { (mths) }\end{array}$} & \multirow[b]{2}{*}{$\begin{array}{l}\text { Resection to } \\
\text { re-implant } \\
\text { (wks) }\end{array}$} & \multirow[b]{2}{*}{$\begin{array}{l}\text { Prior surgical attempts at } \\
\text { eradicating infection }\end{array}$} & \multirow{2}{*}{$\begin{array}{l}\text { Diagnosis of infection } \\
\text { Pre-operative radiological } \\
\text { evidence of infection }\end{array}$} \\
\hline & & & & & & & & \\
\hline 1 & $\mathrm{~F}$ & 82 & No & 1 & 51 & $N / A^{\dagger}$ & Yes & \\
\hline 2 & $\mathrm{~F}$ & 47 & Yes & 1 & 52 & $\mathrm{~N} / \mathrm{A}$ & Yes & No humeral stem loosening \\
\hline 3 & $\mathrm{~F}$ & 72 & Yes & 1 & 48 & $\mathrm{~N} / \mathrm{A}$ & No & No humeral stem loosening \\
\hline 4 & $\mathrm{~F}$ & 56 & Yes & 1 & 48 & $\mathrm{~N} / \mathrm{A}$ & No & No humeral stem loosening \\
\hline 5 & $\mathrm{M}$ & 66 & Yes & 1 & 42 & $\mathrm{~N} / \mathrm{A}$ & Yes & No humeral stem loosening \\
\hline 6 & $\mathrm{~F}$ & 65 & Yes & 1 & 36 & $\mathrm{~N} / \mathrm{A}$ & No & No humeral stem loosening \\
\hline 7 & $\mathrm{~F}$ & 83 & Yes & 1 & 51 & $\mathrm{~N} / \mathrm{A}$ & No & No humeral stem loosening \\
\hline 8 & $\mathrm{M}$ & 73 & Yes & 1 & 49 & $\mathrm{~N} / \mathrm{A}$ & Yes & $\begin{array}{l}\text { Complete radiolucency } \\
\text { around humeral stem }\end{array}$ \\
\hline 9 & $\mathrm{M}$ & 69 & No & 1 & 36 & $\mathrm{~N} / \mathrm{A}$ & Yes & \\
\hline $10^{\ddagger}$ & $\mathrm{M}$ & 61 & No & 1 & 40 & $\mathrm{~N} / \mathrm{A}$ & Yes & \\
\hline 11 & $\mathrm{M}$ & 74 & No & 2 & 49 & 12 & Yes & \\
\hline 12 & $\mathrm{M}$ & 43 & Yes & 2 & 66 & 9 & No & $\begin{array}{l}\text { Complete radiolucency } \\
\text { around humeral stem }\end{array}$ \\
\hline 13 & $\mathrm{~F}$ & 77 & Yes & 2 & 61 & 11 & No & No humeral stem loosening \\
\hline 14 & $\mathrm{M}$ & 79 & Yes & 2 & 44 & 25 & No & $\begin{array}{l}\text { Complete radiolucency } \\
\text { around humeral stem }\end{array}$ \\
\hline 15 & $\mathrm{~F}$ & 67 & Yes & 2 & 51 & 12 & No & No humeral stem loosening \\
\hline 16 & $\mathrm{M}$ & 71 & Yes & 2 & 25 & 11 & No & $\begin{array}{l}\text { Complete radiolucency } \\
\text { around humeral stem }\end{array}$ \\
\hline 17 & $\mathrm{~F}$ & 64 & Yes & 2 & 35 & 12 & No & No humeral stem loosening \\
\hline 18 & $\mathrm{M}$ & 52 & No & 2 & 49 & 12 & Yes & \\
\hline 19 & $\mathrm{M}$ & 56 & Yes & 2 & 27 & 22 & No & No humeral stem loosening \\
\hline 20 & $\mathrm{~F}$ & 70 & Yes & 2 & 26 & 24 & Yes & No humeral stem loosening \\
\hline $21^{\ddagger}$ & $\mathrm{M}$ & 62 & Yes & 2 & 25 & 16 & No & No humeral stem loosening \\
\hline 22 & $\mathrm{~F}$ & 79 & Yes & 5 & 34 & 28 & No & No humeral stem loosening \\
\hline
\end{tabular}

* RSP, reverse shoulder prosthesis

† N/A, not applicable

\# Shoulders 10 and 21 are from the same patient

Ten of the 22 shoulders $(45 \%)$ were treated with a singlestage exchange to a reverse shoulder arthroplasty, and 12 $(55 \%)$ had a two-stage procedure with debridement and antibiotic spacer, followed by conversion to a reverse arthroplasty. In the staged patients, the mean time to reimplantation was 16.2 weeks (9 to 28 ).

Diagnosis. Before surgery, all patients had clinical and radiological evidence of a deficient rotator cuff and glenohumeral instability which was confirmed at operation (Table I). The clinical diagnosis of infection was based on a combination of symptoms, laboratory tests, findings on physical examination, such as a draining sinus, radiological evidence of loosening of the prosthesis (defined as a complete lucent line of $2 \mathrm{~mm}$ or more around the stem of the hemiarthroplasty) (Fig. 1), ${ }^{4}$ radioisotope scanning, and analysis of intra-operative specimens. The blood tests had typically been collected within two weeks of the exchange arthroplasty. The white blood cell (WBC) count was considered to be elevated when it was $>11.0 \times 10^{9} / \mathrm{L}$, erythrocyte sedimentation rate $(\mathrm{ESR})>22 \mathrm{~mm} / \mathrm{h}$ and the C-reactive protein $(\mathrm{CRP})$ level $>1 \mathrm{~d} / /$. Pre-operative WBC counts were available for 16 of the 22 shoulders $(73 \%)$, the ESR was known in ten $(46 \%)$, and the CRP in nine $(41 \%)$. One patient, for whom there was no information on the ESR or CRP, had rheumatoid arthritis. No other patient had a history of this or other inflammatory conditions that might have elevated the ESR or CRP. Indium bone scans were performed on five shoulders and the results reviewed by independent radiologists. They were interpreted as positive, negative or indeterminate.

At operation, four specimens of tissue or bone $1 \mathrm{~cm}$ in size were placed in a sterile container, one in an anaerobic transport medium, and one in formalin for permanent section. Fluid was cultured for aerobes, anaerobes and acidfast bacilli. Gram and acid-fast stains were performed during the procedure, as were frozen sections which were examined for acute inflammation, using the Mirra criteria. ${ }^{5}$ A frozen section was thus considered to be positive when any single high-power field contained at least five polymorphonuclear leukocytes (PMNs). A specimen was frozen for potential re-culture in the future if deemed necessary. Standard incubation plates were held for two days and broth for 14 days. The smears for acid-fast bacilli were held for one day and incubated for eight weeks.

Treatment. All patients underwent debridement and implantation of the Reverse Shoulder Prosthesis (Encore Medical Corporation, Austin, Texas) by two of the authors (MAF, MM; Fig. 2), and a post-operative course of IV antibiotics. The surgeons selected a staged or unstaged conversion based on a subjective assessment of the adequacy of 


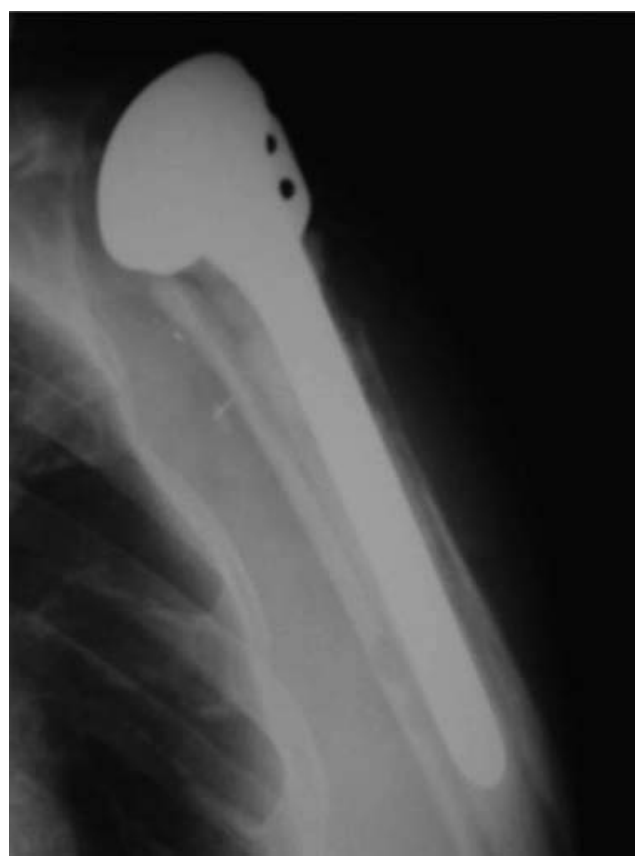

Fig. 1

Anteroposterior radiograph of a hemiarthroplasty with loosening indicative of infection.

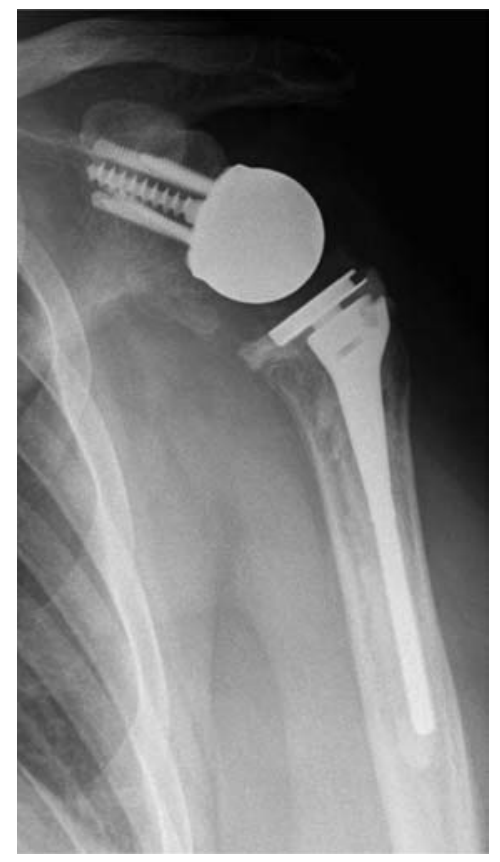

Fig. 2

Anteroposterior radiograph of an implanted early-generation reverse shoulder prosthesis as part of the treatment for an infected shoulder joint. the debridement, the age and comorbidities of the patient, and the accompanying pathology including bone loss, which might require an allograft.

Patients who had a draining sinus before operation or evidence of pus during the operation were treated with six weeks of antibiotics post-operatively as also were those with positive frozen sections or positive permanent sections with or without positive intra-operative cultures. Those with negative frozen and permanent sections but positive intra-operative cultures were given antibiotics for two weeks, as it was felt that positive cultures with negative histology could potentially represent contamination.

Outcome measures. Patients filled in questionnaires prior to, and at a minimum of two years, after surgery. The American Shoulder and Elbow, ${ }^{6}$ visual analogue scale (VAS), ${ }^{7}$ and simple shoulder test ${ }^{8,9}$ scores were derived from these questionnaires, along with the subjective satisfaction rating of the patient, graded as excellent, good, satisfactory or unsatisfactory. The active range of forward flexion, abduction and external rotation was measured before operation, and at follow-up at a minimum of two years.

The radiological assessment of all the patients was carried out by an orthopaedic surgeon (DJC) not involved in the treatment. The pre-operative and the most recent radiographs were evaluated. Each series consisted of anteroposterior (AP), true AP, axillary and scapular Y lateral films. The pre-operative radiographs were examined for evidence of instability based on the criteria of Sperling et $\mathrm{al},{ }^{4}$ the presence of glenoid erosion, ${ }^{10}$ and a radiolucent line $\geq 2 \mathrm{~mm}$ in width in three or more zones around the humeral component. $^{4,11}$ The post-operative films were evaluated for loosening of the humeral baseplate, scapular notching, and any other incidental findings.

Statistical methods. The pre- and post-operative outcome measures, including the American Shoulder and Elbow, ${ }^{6}$ VAS, ${ }^{7}$ and simple shoulder test scores, ${ }^{8,9}$ and the active ranges of movement were compared using a paired $t$-test for normally distributed data or Wilcoxon's signed ranks test for non-parametric data. The outcome of one- and multiple-stage procedures were compared using Student's $t$-test for normally distributed data or a Mann-Whitney $U$ test for non-parametric data. Statistical analysis was performed using MedCalc version 8.2.1.0 (Mariakerke, Belgium). A p-value $<0.05$ was considered significant.

\section{Results}

Pre-operative findings. Before operation physical examination showed obvious signs of infection in 16 shoulders $(73 \%)$. There was a sinus tract in $12(75 \%)$ and a swollen erythematous joint in four $(25 \%)$. Of the 16 shoulders with WBC counts before operation, none was elevated. Of the ten shoulders for which an ESR was available, it was elevated in seven. Nine of the 22 shoulders $(41 \%)$ had measurement of the CRP before operation, and this was elevated in six $(67 \%)$. The pre-operative indium-labelled 
bone scan was positive in two of the five shoulders tested. Some level of glenohumeral instability was seen on the radiographs available for 18 shoulders before operation. Five $(28 \%)$ had mild subluxation, in six $(33 \%)$ it was moderate, and in seven $(39 \%)$ severe. Erosion of the glenoid was seen in the radiographs of all 18 shoulders. An area of radiolucency $\geq 2 \mathrm{~mm}$ was seen around all zones of the implant in four shoulders, suggesting infection (Fig. 1).

Intra-operative findings. At operation, frozen sections showed evidence of acute inflammation in 15 of 22 shoulders $(68 \%)$, either during the reverse shoulder procedure or at an intermediate stage. Acute inflammatory changes were seen in 13 permanent sections (59\%). Positive cultures at operation were obtained in 18 of 22 shoulders ( $82 \%)$. Of the four shoulders with negative intra-operative cultures, three showed evidence of acute inflammation on histological examination, but the other one had clinical signs. Staphylococcus aureus was the most common organism encountered (Table II).

Post-operative radiographs. Inspection of the last available radiographs showed one patient (one shoulder) with complete radiolucency around the humeral component and another with lucency around the baseplate, which had not migrated. This latter patient had an aspiration of the joint and appropriate blood tests both of which were negative.

There were no instances of scapular notching. Other findings noted on the last available radiographs included one shoulder with broken screws and a peri-prosthetic fracture, grade IV Brooker heterotopic ossification in two shoulders, and dissociation of the polyethylene component in another (Table II).

Complications. There were 11 complications in seven shoulders (Table II). Two occurred on the glenoid side of the joint. One shoulder with severe bone loss from the posterior glenoid had breakage of the central baseplate screw and a periprosthetic scapular fracture. The general condition of the patient did not allow an attempt at revision. Another patient had loosening of both components one year after operation. The reverse shoulder prosthesis was converted to a longstemmed humeral component. Neither of these patients had evidence of further infection.

There were six complications on the humeral side with two polyethylene dissociations, a peri-prosthetic fracture, a radial nerve palsy, a dislocation, and the loosening mentioned above. One patient fell at 23 months and fractured the polyethylene component, with dissociation. He underwent revision with a polyethylene exchange and a proximal humeral allograft. Another patient who was treated in a staged fashion had a fracture just distal to the antibioticcoated hemiarthroplasty spacer and developed a radial nerve palsy. This was treated by removal of the spacer and internal fixation of the fracture, followed by conversion to the reverse shoulder arthroplasty seven days later. This patient subsequently had polyethylene dissociation 16 months after the reverse arthroplasty. Her general health ruled out further surgery. She had reasonable function and rated her outcome as excellent. Dislocation occurred in one shoulder 19 days after operation. It was successfully managed by closed reduction.

There were three shoulders with a post-operative haematoma which required incision and drainage within the first three weeks after their arthroplasty. Two were in the staged group, the other was a single-stage conversion. No evidence of infection was found and the wounds healed without further problems.

Functional outcomes. All outcome measures improved significantly (Table III). The mean abduction improved from $36.1^{\circ}$ (SD 27.8) to $75.7^{\circ}$ (SD 36.0) post-operatively (paired ttest, $\mathrm{p}<0.0001)$, and mean forward flexion improved from $43.1^{\circ}$ (SD 33.5) to $79.5^{\circ}$ (SD 43.2) ( $\left.\mathrm{p}=0.0003\right)$. Mean external rotation improved from $10.2^{\circ}$ (SD 18.7) to $25.4^{\circ}$ (SD $23.5)(\mathrm{p}=0.0037)$. Forward flexion improved in 19 of 22 shoulders $(86 \%)$. Abduction improved in 19 of the 21 shoulders $(90 \%)$ for which the data was available. External rotation improved in 14 of 22 shoulders (64\%). The mean total American Shoulder and Elbow scores improved from 31.9 (SD 18.9) to 57.0 (SD 27.0) ( $\mathrm{p}<0.0001)$. The mean American Shoulder and Elbow pain scores improved from 18.3 (SD 10.7) to 32.4 (SD 15.1) ( $<<0.0001)$, and the mean American Shoulder and Elbow function scores improved from 13.6 (SD 10.6) to 24.6 (SD 14.6) ( $\mathrm{p}=0.0001)$. The mean visual analogue scale pain scores improved from 6.3 (SD 2.1) to 3.5 (SD 3.0) ( $\mathrm{p}<0.0001)$, and the mean VAS function scores improved from 1.8 (SD 1.8) to 4.8 (SD 3.3) $(\mathrm{p}=0.0012)$. The mean Simple Shoulder test scores in the 21 shoulders about which we had data improved from 1.3 (SD 1.6) to 4.0 (SD 3.0) ( $<<0.0001)$. There were 14 shoulders $(64 \%)$ which were rated as good or excellent, five $(23 \%)$ as satisfactory, and three $(13 \%)$ as unsatisfactory. In addition to the patient with the peri-prosthetic scapular fracture mentioned above, one of the dissatisfied patients had heterotopic ossification and poor movement, and the other had only marginal improvement in pain and function, but no complications or abnormal radiological findings.

Compared with their pre-operative scores, 18 of 22 shoulders $(82 \%)$ showed an improvement in the post-operative VAS and American Shoulder and Elbow pain scores and 17 of $22(77 \%)$ showed improvement in the post-operative American Shoulder and Elbow function scores. Of the 22, 19 $(86 \%)$ showed improvement in their total American Shoulder and Elbow scores, 15 (68\%) had improvement in their VAS functional scores, and 18 of $21(86 \%)$ had improved Simple Shoulder test scores. The pre-operative Simple Shoulder test score was not available for one shoulder.

No significant difference was found for any of the outcome measures when comparing single- with multiple-stage procedures. Neither the pre-operative assessments nor post-operative outcome measures were significantly different. None of the patients had evidence of recurrent infection at the last follow-up and the two patients with radiological evidence of failure had no evidence of infection after comprehensive reassessment. 
Table II. Signs and diagnostic tests for infection, complications, and patient reported outcomes

\begin{tabular}{|c|c|c|c|c|c|c|c|c|c|}
\hline \multirow[b]{2}{*}{ Shoulders } & \multicolumn{3}{|c|}{ Diagnosis of infection } & \multirow[b]{2}{*}{$\begin{array}{l}\text { Abnormal } \\
\text { findings on last } \\
\text { available } \\
\text { post-operative } \\
\text { radiographs }\end{array}$} & \multirow[b]{2}{*}{$\begin{array}{l}\text { Pre-operative } \\
\text { ASES }^{\dagger} \text { score }\end{array}$} & \multirow[b]{2}{*}{$\begin{array}{l}\text { Post-opera- } \\
\text { tive ASES } \\
\text { score }\end{array}$} & \multirow[b]{2}{*}{ Complications } & \multirow[b]{2}{*}{$\begin{array}{l}\text { Re-operation } \\
\text { after reverse }\end{array}$} & \multirow[b]{2}{*}{$\begin{array}{l}\text { Patient } \\
\text { satisfaction }\end{array}$} \\
\hline & $\begin{array}{l}\text { Clinical } \\
\text { or intra- } \\
\text { opera- } \\
\text { tive sign }\end{array}$ & Cultures $^{*}$ & Final histology & & & & & & \\
\hline 1 & Yes & MSSA, MRSA & Acute inflammation & None & 27.5 & 62.5 & None & No & Good \\
\hline 2 & No & Negative & Acute inflammation & None & 50 & 50 & None & No & Good \\
\hline 3 & Yes & Negative & Acute inflammation & $\begin{array}{l}\text { Broken screws: } \\
\text { Peri-prosthetic } \\
\text { scapular } \\
\text { fracture }\end{array}$ & 40 & 32.5 & $\begin{array}{l}\text { Peri-prosthetic } \\
\text { scapular } \\
\text { fracture }\end{array}$ & No & Dissatisfied \\
\hline 4 & No & Staphylococcus & $\begin{array}{l}\text { No acute } \\
\text { inflammation }\end{array}$ & None & 15 & 57.5 & None & No & Excellent \\
\hline 5 & No & $\begin{array}{l}\text { Coagulase } \\
\text { negative } \\
\text { staphylococcus }\end{array}$ & $\begin{array}{l}\text { No acute } \\
\text { inflammation }\end{array}$ & None & 17.5 & 50 & None & No & Satisfied \\
\hline 6 & No & $\begin{array}{l}\text { Candida } \\
\text { albicans }\end{array}$ & $\begin{array}{l}\text { Acute } \\
\text { inflammation }\end{array}$ & None & 32.5 & 72.3 & None & No & Good \\
\hline 7 & No & Negative & $\begin{array}{l}\text { Acute } \\
\text { inflammation }\end{array}$ & None & 40 & 40 & None & No & Dissatisfied \\
\hline 8 & Yes & E. faecalis & $\begin{array}{l}\text { Acute } \\
\text { inflammation }\end{array}$ & None & 47.5 & 78.3 & $\begin{array}{l}\text { Fractured } \\
\text { polyethlene }\end{array}$ & Yes & Satisfied \\
\hline 9 & Yes & Negative & $\begin{array}{l}\text { No acute } \\
\text { inflammation }\end{array}$ & None & 45 & 100.0 & $\begin{array}{l}\text { Haematoma vs } \\
\text { seroma }\end{array}$ & Yes & Good \\
\hline $10^{\ddagger}$ & Yes & MRSA & Acute inflammation & None & 45 & 83.3 & None & No & Satisfied \\
\hline 11 & Yes & $\begin{array}{l}\alpha \text {-streptococci } \\
\text { coagulase } \\
\text { negative } \\
\text { staphylococcus }\end{array}$ & Acute inflammation & None & 65 & 90 & None & No & Excellent \\
\hline 12 & Yes & Micrococcus & Acute inflammation & None & 30 & 45 & None & No & Satisfied \\
\hline 13 & Yes & E. cloacae & $\begin{array}{l}\text { No acute } \\
\text { inflammation }\end{array}$ & None & 10 & 13.3 & $\begin{array}{l}\text { 1. Dislocation } \\
\text { 2. Haematoma }\end{array}$ & Yes & Excellent \\
\hline 14 & Yes & Staphylococcus & Acute inflammation & $\begin{array}{l}\text { Grade IV Booker } \\
\text { heterotopic } \\
\text { ossification }\end{array}$ & 15 & 20 & Seroma & Yes & Excellent \\
\hline 15 & Yes & $\begin{array}{l}\text { Multiple } \\
\text { organisms }\end{array}$ & Acute inflammation & None & 25 & 85 & None & No & Good \\
\hline 16 & Yes & $\begin{array}{l}\text { Staphylococ- } \\
\text { cus, P. acnes }\end{array}$ & Acute inflammation & None & 15 & 30 & None & No & Good \\
\hline 17 & Yes & $\begin{array}{l}\text { Coagulase } \\
\text { negative } \\
\text { staphylococcus }\end{array}$ & Acute inflammation & $\begin{array}{l}\text { Humeral loos- } \\
\text { ening } \\
\text { Grade IV hetero- } \\
\text { topic ossifica- } \\
\text { tion }\end{array}$ & 0 & 20 & None & No & Dissatisfied \\
\hline 18 & No & Serratia & $\begin{array}{l}\text { No acute } \\
\text { inflammation }\end{array}$ & None & 22.5 & 23.3 & None & No & Excellent \\
\hline 19 & Yes & P acnes & $\begin{array}{l}\text { No acute } \\
\text { inflammation }\end{array}$ & None & 62.5 & 90 & None & No & Good \\
\hline 20 & Yes & $\begin{array}{l}\text { Coagulase } \\
\text { negative } \\
\text { staphylococcus }\end{array}$ & $\begin{array}{l}\text { Acute } \\
\text { inflammation }\end{array}$ & None & 42.5 & 65 & $\begin{array}{l}\text { 1. Baseplate } \\
\text { loosening } \\
\text { 2. Humeral } \\
\text { loosening }\end{array}$ & Yes & Good \\
\hline $21^{\ddagger}$ & Yes & MRSA & Acute inflammation & None & 55 & 80 & None & No & Satisfied \\
\hline 22 & Yes & MRSA & $\begin{array}{l}\text { No acute } \\
\text { inflammation }\end{array}$ & $\begin{array}{l}\text { Baseplate loos- } \\
\text { ening without } \\
\text { migration; some } \\
\text { absorption of } \\
\text { allograft; Poly- } \\
\text { ethylene disas- } \\
\text { sociation }\end{array}$ & 0 & 15 & $\begin{array}{l}\text { 1. Peri-pros- } \\
\text { thetic humeral } \\
\text { fracture } \\
\text { 2. Radial nerve } \\
\text { palsy } \\
\text { 3. Poly } \\
\text { dissociation }\end{array}$ & No & Excellent \\
\hline
\end{tabular}

* MSSA, methicillin sensitive staphylococcus aureus; MRSA, methicillin-resistant staphylococcus aureus

† ASES, American shoulder and elbow score

$\ddagger$ Shoulders 10 and 21 are from the same patient

\section{Discussion}

The treatment of post-operative deep infection of the shoulder has included long courses of intravenous antibiotics, ${ }^{1}$ debridement with retention of the prosthesis, ${ }^{12}$ resection arthroplasty, ${ }^{12-15}$ single-stage exchange, ${ }^{16}$ delayed reimplantation, ${ }^{13}$ arthrodesis ${ }^{17}$ and amputation. ${ }^{18}$
The use of intravenous antibiotics alone, or debridement with retention of the prosthesis had a high rate of recurrent infection of $60 \%$ and $63 \% .^{12}$ Resection arthroplasty has a lower rate of recurrence, but limited functional improvement. ${ }^{12-14}$ Sperling et $\mathrm{al}^{13}$ found the two-stage procedure to have the best outcome, with all three patients free from 
Table III. Patient outcomes (mean \pm standard deviation)

\begin{tabular}{lcrr}
\hline & Pre-operative & Post-operative & p-value \\
\hline Patient reported & & & \\
ASES pain & $18.3(10.7)$ & $32.4(15.1)$ & $<0.0001$ \\
ASES function & $13.6(10.6)$ & $24.6(14.6)$ & 0.0001 \\
Total ASES & $31.9(18.9)$ & $57.0(27.0)$ & $<0.0001$ \\
VAS pain & $6.3(2.1)$ & $3.5(3.0)$ & $<0.0001$ \\
VAS function & $1.8(1.8)$ & $4.8(3.3)$ & 0.0012 \\
SST & $1.3(1.6)$ & $4.0(3.0)$ & $<0.0001$ \\
& & & \\
Range of movement $\left(^{\circ}\right)$ & & $79.5(43.2)$ & 0.0003 \\
Forward flexion & $43.1(33.5)$ & $75.7(36.0)$ & $<0.0001$ \\
Abduction & $36.1(27.8)$ & $25.4(23.5)$ & 0.0037 \\
External rotation & $10.2(18.7)$ & & \\
* ASES, American Shoulder and Elbow score ${ }^{6}$ VAS, visual analogue scale ${ }^{7}$ SST, simple shoulder
\end{tabular}

test score ${ }^{9}$

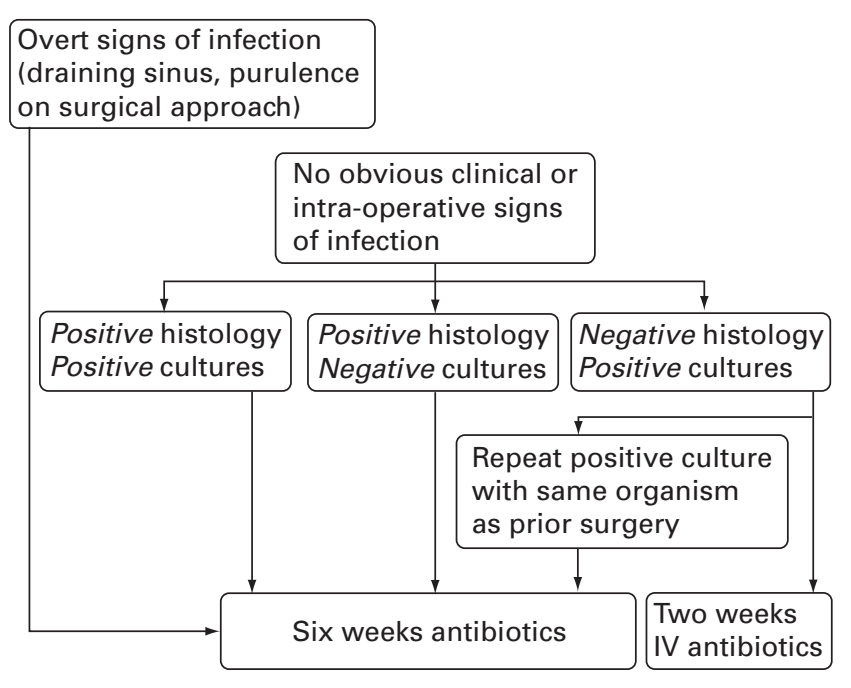

Fig. 3

Algorithm for post-operative intravenous (IV) antibiotics after shoulder arthroplasty for infection.

infection at the last follow-up. These patients had a mean active abduction of $100^{\circ}$. Ince et $\mathrm{al}^{16}$ managed 16 infected shoulder arthroplasties with a single-stage exchange. None had a recurrence of infection at their last follow-up, but the functional results were less satisfactory, with a mean active abduction of $51.6^{\circ}$. The authors considered that debridement of infected tissue, including the rotator cuff, may have contributed to the restricted movement. Given the amount of rotator cuff dysfunction, they suggested that the reverse design might be a better alternative in these patients. The one patient treated with a reverse design had a good outcome, with only slight pain and active abduction of $110^{\circ} .{ }^{16}$

The absence of recurrent infection in our current series is a direct result we think, of the quality of the debridement performed at the index procedure. By anticipating the use of a reverse shoulder arthroplasty, there was little concern about removing suspicious soft tissue or bone, including resection of infected portions of the rotator cuff, capsule and bone. The only structure it was necessary to preserve was the deltoid muscle, which is the main muscle determining function after reverse shoulder arthroplasty. Despite such aggressive debridement, functional improvement was consistently seen after conversion to the reverse shoulder arthroplasty. This re-establishes the stable fulcrum needed for the optimal performance of the deltoid. ${ }^{19}$

The complication rate in this series was $32 \%$ (7 of 22 ). This can be attributed to the difficult nature of this problem, and the many previous operations that some of these patients had undergone. Reverse shoulder arthroplasty as a revision procedure has been reported as having a complication rate approaching $50 \% .^{20}$ Many of the patients in our series were treated with the earliest generation of this implant, which used $3.5 \mathrm{~mm}$ peripheral screw fixation with an all-polyethylene humeral component. We currently use $5.0 \mathrm{~mm}$ peripheral locking screws, as this has been shown to be a stronger construct. ${ }^{21}$ We have also added a metal shell to support the humeral component, thereby minimising the risk of fracture or dissociation which occurred in two patients.

The diagnosis of a post-operative infection can be difficult. Suggested protocols have been based on experience with hip and knee arthroplasty, and adapted for the shoulder. $^{22}$

The use of a standardised procedure for processing and examining intra-operative tissue can provide the surgeon with reliable information about infection and reduce the number of false negatives caused by improper tissue handling or inadequate specimen collection. We use an algorithm, which includes clinical signs of infection, intraoperative histology and cultures to determine the duration of the use of intravenous antibiotics (Fig. 3). Most patients were treated for six weeks. In future, the use of newer techniques, such as polymerase chain reaction, which is being used to detect bacteria that may be present in very low 
inoculum, or that do not grow in culture, may be useful in helping to establish the diagnosis. ${ }^{23,24}$

As regards outcome and the eradication of infection, a single-stage revision was statistically no different from a two-stage procedure. This may be because of the fact that a more aggressive debridement can be undertaken if a reverse shoulder arthroplasty is used. One criticism is the lack of a standardised algorithm to guide whether a single- or twostage procedure should be undertaken. The intra-operative decision was made based on the appearance of the tissue and the adequacy of debridement, as well as the possible need for an allograft.

The major weaknesses of this study are that it is retrospective in nature and the follow-up is short. We continue to follow this group of patients closely to assess possible recurrent infection.

No benefits in any form have been received or will be received from a commercial party related directly or indirectly to the subject of this article.

\section{Supplementary Material}

$\because$ A supplementary table comparing various treatments C for deep infection of the shoulder joint is available with the electronic version of this article on our website at www.jbjs.org.uk

\section{References}

1. Zalavras CG, Patzakis MJ. Open fractures: evaluation and management. J Am Acad Orthop Surg 2003;11:212-19.

2. Neubauer T, Bayer GS, Wagner M. Open fractures and infection. Acta Chir Orthop Traumatol Cech 2006;73:301-12.

3. Nast-Kolb D, Schweiberer L. Treatment concept in infected bone and soft tissue defects. Orthop 1994;23:430-6.

4. Sperling JW, Cofield RH, O'Driscoll SW, Torchia ME, Rowland CM. Radiographic assessment of ingrowth total shoulder arthroplasty. J Shoulder Elbow Surg 2000;9:507-13.

5. Mirra JM, Amstutz HC, Matos M, Gold R. The pathology of the joint tissues and its clinical relevance in prosthesis failure. Clin Orthop 1976;117:221-40.

6. Richards RR, An KN, Bigliani LU, et al. A standardized method for the assessment of shoulder function. J Shoulder Elbow Surg 1994;3:347-52.
7. Wewers ME, Lowe NK. A critical review of visual analogue scales in the measurement of clinical phenomena. Res Nurs Health 1990;13:227-36.

8. Beaton D, Richards RR. Assessing the reliability and responsiveness of five shoulder questionnaires. J Shoulder Elbow Surg 1998;7:565-72.

9. Matsen FA III, Lippitt SB, De Bertolo SE. Principles of evaluation. In: Shoulder surgery: principles and procedure. Toronto: WB Saunders Company, 1994:4-5.

10. Antuna SA, Sperling JW, Cofield RH, Rowland CM. Glenoid revision surgery after total shoulder arthroplasty. J Shoulder Elbow Surg 2001;10:217-24.

11. Sanchez-Sotelo J, O'Driscoll SW, Torchia ME, Cofield RH, Rowland CM. Radiographic assessment of cemented humeral components in shoulder arthroplasty. J Shoulder Elbow Surg 2001;10:526-31.

12. Coste JS, Reig S, Trojani C, et al. The management of infection in arthroplasty of the shoulder. J Bone Joint Surg [Br] 2004;86-B:65-9.

13. Sperling JW, Kozak TK, Hanssen AD, Cofield RH. Infection after shoulder arthroplasty. Clin Orthop 2001;382:206-16.

14. Braman JP, Sprague M, Bishop J, et al. The outcome of resection shoulder arthroplasty for recalcitrant shoulder infections. J Shoulder Elbow Surg 2006;15:549-53.

15. Rispoli DM, Sperling JW, Athwal GS, Schleck CD III, Cofield RH. Pain relief and functional results afer resection arthroplasty of the shoulder. J Bone Joint Surg [Br] 2007;89-B:1184-7.

16. Ince A, Seemann K, Frommelt L, Katzer A, Loehr JF. One-stage exchange shoulder arthroplasty for peri-prosthetic infection. J Bone Joint Surg [Br] 2005;87-B:814-

17. Clare DJ, Wirth MA, Groh GI, Rockwood CA Jr. Shoulder arthrodesis. J Bone Joint Surg [Am] 2001;83-A:593-600.

18. Unglaub F, Guehring T, Fichs PC, et al. Necrotizing fasciitis following therapeutic injection in a shoulder joint. Orthopade 2005;34:250-2 (in German).

19. Frankle M, Siegal S, Pupello D, et al. The reverse shoulder prosthesis for glenohumeral arthritis associated with severe rotator cuff deficiency: a minimum two-year follow-up study of sixty patients. J Bone Joint Surg [Am] 2005;87-A:1697-705

20. Werner CM, Steinmann PA, Gilbert M, Gerber C. Treatment of painful pseudoparesis due to irreparable rotator cuff dysfunction with the Delta III reverse-ball-andsocket total shoulder prosthesis. J Bone Joint Surg [Am] 2005;87-A:1476-86.

21. Harman $\mathbf{M}$, Frankle $\mathbf{M}$, Vasey $\mathbf{M}$, Banks $\mathbf{S}$. Initial glenoid component fixation in "reverse" total shoulder arthroplasty: a biomechanical evaluation. J Shoulder Elbow Surg 2005; 14:1625-75.

22. Bauer TW, Parvizi J, Kobayashi N, Krebs V. Diagnosis of periprosthetic infection J Bone Joint Surg [Am] 2006;88-A:869-82.

23. Tunney MM, Patrick S, Curran MD, et al. Detection of prosthetic hip infection a revision arthroplasty by immunofluorescence microscopy and PCR amplification of the bacterial 16S rRNA gene. J Clin Microbial 1999;37:3281-90

24. Trampuz A, Steckelberg JM, Osmon DR, et al. Advances in the laboratory diagnosis of prosthetic joint infection. Rev Med Microbio/ 2003;14:1-14 